\title{
IMPROVING STUDENTS' VOCABULARY MASTERY THROUGH WORD SQUARE MODELING AT GRADE VII SMP NEGERI 5 PADANGSIDIMPUAN
}

\author{
SERI MAWAR, EKA SUSTRI HARIDA, \& FITRI RAYANI SIREGAR \\ IAIN Padangsidimpuan \\ email: haridaekasustri75@gmail.com
}

\begin{abstract}
Abstrak
Penelitian ini untuk mengetahui peningkatan kemampuan penguasaan kosakata bahasa Inggris siswa dengan menggunakan sebuah teknik pembelajaran yakni Word Square Modelling. Penelitian dilakukan dengan metode penelitian tindakan kelas dengan memilih siswa kelas VII SMP Negeri 5 sebagai subject penelitian. Dua siklus dilakukan dalam penelitian ini dengan mengikuti 4 (empat) proses dalam setiap siklusnya, yakni planning, observing, acting, and reflecting. Tes vocabulary digunakan untuk mengetahui kemampuan penguasaan vocabulary siswa yang dilakukan analiss dengan mencari tahu nilai rata-rata dan persentase nilai yang diperoleh oleh siswa. Hal lain yang dilakukan adalah melakukan observasi dan wawancara untuk menyempurnakan pemerolehan data penelitian. Dari analisis data yang dilakukan diketahui bahwa pesentase nilai penguasaan vocabulary siswa dari siklus satu ke siklus beirkutnya meningkat, yakni dari $76,19 \%$ menjadi 78.66 . walaupun peningkatan yang terjadi tidak begitu tinggi, namun dapat disimpulkan bahwa penggunakan wodd square modeling untuk mengajari vocabulary mastery sungguh baik digunakan.
\end{abstract}

Kata Kunci: Peningkatan, Kosakata, dan Word Square Model.

\begin{abstract}
This research focused about Improving Students' Vocabulary Mastery through Word square Modeling at Grade VII SMP Negeri 5 Padangsidimpuan. The objective this research was to find whether teaching vocabulary by using word square modeling can improve students' vocabulary mastery at grade VII of SMP Negeri 5 Padangsidimpuan This research was conducted by classroom action research. The participants of this research was students at grade VII of SMP Negeri 5 Padangsidimpuan consisted of 21 students. This research used test, interview and observation as instrument. Test was used to find out the score of students' vocabulary mastery, then find out mean score and percentage as formulation. Next, interview and
\end{abstract}


observation were used to know condition and to contribute the test. Based on the result of this research, the students' vocabulary mastery was improved with percentage in the first cycle $42.85 \%$ and in the second cycle was $76.19 \%$. So that, there was $34 \%$ improvement. It was suitable with mean score of students' vocabulary mastery that had been gotten in the first cycle. It was 73 improved into 78.66 in the second cycle. Finally, students' vocabulary mastery could be improved by using word square modeling. So, it was recommended that word square modeling could be used in teaching learning vocabulary in classroom based on this research.

Keyword: Improving, Vocabulary and Word Square Model

\section{INTRODUCTION}

English is an international language. In Indonesia is one of important learning in school. Moreover, English becomes the only foreign language which is include in National Examination or can be called Ujian Nasional from junior high school until senior high school. ${ }^{1}$ Hence, it become one of some decisionmaker-subjects for the students graduation to know how well they understand English during their study. So, learning English has been important thing to do.

Vocabulary refers to the collection of word. Vocabulary is the total number of the words. ${ }^{2}$ Vocabulary is important not merely in educational world but in daily activities. Vocabulary is recognized as the perfect instrument of language and language is recognized as the perfect instrument communication, because it is one important matter in language. When doing communication, the people will understand each other because they use vocabulary.

According to syllabus and handbook at grade VII Junior High School, vocabulary is important subject matter. Study about vocabulary and structure relevant to noun phrase, adjective, adverb and verb by asking and giving service, asking and giving goods, asking and giving fact. ${ }^{3}$ Based on the syllabus students must be able to develop their vocabulary. Because all of subject matter needs vocabulary.

${ }^{1}$ Peraturan Pemerintahan Republik Indonesia No. 32 Tahun 2013 tentang Perubahan atas Peraturan Pemerintahan No. 19 Tahun 2005 Tentang Standar Nasional Pendidikan, Pasal 70 ayat 3, (Ditetapkan di Jakarta: 7 Mei 2013).

${ }^{2}$ A.S Hornby, Oxford Advanced Learner's Dictionary of Current English, Oxford University Press: 1995) p. 1331.

${ }^{3}$ SMP Negeri 5 Padangsidimpuan, Perangkat Pembelajaran Panduan Pengembangan Silabus Pembelajaran,(Padangsidimpuan:2014), p.105. 
Based on statement above, vocabulary is important in this life and education, wherever and whenever the people need vocabulary for communication. Futhermore at the grade VIISMP Negeri 5 Padangsidimpuan is problematic, it is happened because the students don't understand about their lesson, the students less in vocabulary mastery, and most of students' vocabulary value is far from the goals which have been determined. ${ }^{4}$

Students also lack motivation to memorize vocabulary at grade VII in SMP Negeri 5 Padangsidimpuan. They don't interest to memorize vocabulary and they hate English because they think English is very difficult, as a result most of the students don't understand about English. It can be happened because of strategies for teaching and learning it not appropriate with students.

Based on the problems above, the researcher feels important to solve the problems because students are product of education. There are some models can to improve students' vocabulary mastery like; Word Square Modeling, Picture and Picture Modeling and Scramble Modeling. The researcherchoose Word Square Modeling because students in this agemore interest to games, they will study about English whit simple form. Variety of games in teaching will add students' spirit to learn English especially in vocabulary.

Word square is a special type of acrostic. It consists of a set of words written out in a square grid, such that the same words can be read both horizontally and vertically. The number of words, which is equal to the number of letters in each word, is known as the "order" of the square" 5 .So researcher will use word square as technique to improve vocabulary mastery. The focus of the research in this research is improving students' vocabulary mastery using word square modeling. Vocabulary about: countable noun, uncountable noun, concrete noun, and abstract noun.

The objectives of this research are to examine the used of word square modeling whether it can improve students' vocabulary mastery at Grade VII SMP Negeri 5 Padangsidimpuan or not, and to evaluate the factors influenced students' vocabulary mastery by using word square modeling at Grade VII SMP Negeri 5 Padangsidimpuan.

${ }^{4}$ Nurhayati Siregar, as English teacher of grade VII, Private Interview, (SMP Negeri 5 Padangsidimpuan, August $24^{\text {th }}, 2015$ on 10 pm).

${ }^{5}$ Zainal Aqib, Model-Model, Media, Dan Strategi Pembelajaran Kontekstual (Inovatif), (Bandung, 2013), p.32 


\section{THEORETICAL DESCRIPTION}

\section{Description of Vocabulary Mastery}

Vocabulary is one of component for the language, where is vocabulary help people to speaking and language communication. Vocabulary is also one of the important things to mastery the four skill like; reading, speaking, listening and writing. "Vocabularyis all thewords that a person know to use, the word the people use when they are talking about particular subject". ${ }^{6}$ According to ShirleyBurridge saysthat "Vocabulary is all the words in language, list of word in a lesson or books, all the words that one person know". ${ }^{7}$ It means vocabulary is all the word in language, lesson or books and all the word that human know.

Addition some defenition of vocabulary, according to Richad and Willy A Renandya say that "Vocabulary is a core component of language proviciency and provides much of the basis how well speaks, listen, read, and write".$^{8}$ It means words can be noun, verb, adjective, adverb, conjunction, preposition to use language. Vocabulary is the stock of word on which they can draw in expressing people selves. Most of the people do not use nearly as many words in speaking or writing as someone recognizes or understands when they hear or see. ${ }^{9}$ It means, someone uses vocabularies which they have been known, and cannot use vocabulary that they have been known yet.

The researcher can conclude that vocabulary is all the words which use in a language and vocabulry is all words that people know or use and also as the core component of words that is list in the alphabetical order.

Mastery the word from master. Master is person very skilled and able in some work, profession, science. While mastery is the expert skill or knowledge. Addition about mastery "Mastery is great knowledge about understanding of a particular thing". It means mastery is a competence someone about one material or to do something.

Based on the statement above the researcher conclude that vocabulary mastery is that great knowledge, control or skill of all word. Vocabulary mastery is ability to memorize many of list vocabulary. Because students must have to

\footnotetext{
${ }^{6}$ A.S. Hornby, p. 1506

7Shirley Burridge, Oxford Basic English Dictionary, (New York: OxfordUniversity Press, 1981), p. 477.

${ }^{8}$ Jack C. Richard \& Willy A. Renandya, Methodology in Language Teaching and Anthology of Current Practice, (USA:Cambridge University Press, 2000), p. 255.

${ }^{9}$ Richard D. Mallery, How to Enlarge and Improve your Vocabulary, (United state, America: The Blakiston Company, 1947), p. 1.
} 
know how to use the words and understanding meaning, so that can express in communication. It means students not only understand the words but also the meaning. It is very important for four our skill and in education there is reading, speaking, listening and writing.

\section{Kinds of Vocabulary}

Many kinds of vocabulary can be used to know some people about their vocabulary. Another word, with many kinds of vocabulary can be used to identify the level of someone; beginner level, intermediate level, or advance level. So, kinds of vocabulary are one of knowledge to know some people about their ability in vocabulary

In this research there are some kinds of the vocabulary, EvelyMarcusen says, "that vocabulary can divided in two kinds, there high frequency vocabulary and low frequency vocabulary". They are below:

1. High frequency vocabulary consist of words that are used very often in normal language, use in all four skill and across the full range situation of used. High frequency of vocabulary consist of 2000 word families, which are about $87 \%$ of the running words in normal writen text and more that $95 \%$ of the words informal spoken texts.

2. The Low frequency on other hand, cover only small propotion of the running words of continuos text. Itmean that low frequency vocabulary is rarely used in common activity of English language. This group includes well over 100.000 word families. ${ }^{10}$

More about kinds of vocabulary Thornbury in Harmer says, there are two kind of vocabulary: Receptive vocabulary or passive vocabulary and Productive vocabulary or active Vocabulary. ${ }^{11}$ There are further explenation is:

1. Receptive Vocabulary or Passive Vocabulary

Receptive vocabulary can be understood only through listening and reading. Someone doesn't need to know musch about the receptive vocabulary because someone rarely uses the receptive vocabulary and it is imposible for someone can understand the ideas of the utterance contextually not word by word.

${ }^{10}$ Evely Marcusen, Vocabulary Semantic and Language Education (Cambridge: University Press. 1997), p. 45. P. 158 .

11Jeremy Harmer, The Practical of English Language Teaching, (New York: Longman, 2000), 
240 | TAZKIR: Jurnal Penelitian Ilmu-ilmu Sosial dan Keislaman

Vol. 03 No. 2 Desember 2017

2. Productive Vocabulary or Active Vocabulary

Poductive Vocabulary involves of knowing how to pronounce the word, how to write and spell it, how to used it in correct grammatical patterns along with the words that usually collocate with.

Based on the statements above the researcher takes conclusion that kinds of vocabulary; An active vocabulary refers to the words students should using in speaking and writing, and passive vocabulary means words they need only to comprehend especially in reading and listening.

In vocabulary there are some kinds of vocabulary are knowledge to know the level someone, but classified of vocabulary is type of vocabulary itself, or division of words. Vocabularies are classified into function and contents of words. The function words are closed class, someone cannot add to the preposition or auxiliaries or modals, or any structure words of language. Addition, to make comprehending about word. The words also still has some classification, such as nouns, pronoun, verb, adjective. Wren and Martin says that words are divided into different kinds or class, called "Parts of Speech", thus parts of Speech are: Noun, Adverb, Adjective, Preposition, Pronoun, Conjuction, Verb, and Interjection". ${ }^{12}$ So, from the explaination above about the part of speech that are included in vocabulary. So the researcher made the focus of the research in this research is focus on noun, they are; countable noun.

\section{Teaching Vocabulary}

Teaching vocabulary is important activity for improving students' vocabulary ability. Teacing vocabulary should be prsented interactively in teaching of four language skills. It is impossible to learning a language without words. So, teaching vocabulary important because can help students to be more understanding when teaching and learning is happened. "In teaching vocabulary, teachers also must provide opportunities to organize vocabulary. It is meaingful ways to make it easier to learn by students. Into the bargain, teacher also must focus on vocabulary". ${ }^{13}$ There are some guidelines for the communicative treatment of vocabulary intruction: ${ }^{14}$

\footnotetext{
${ }^{12}$ Wren and Martin, High School English Grammar and Composition, ( Jakarta:PersadaRao, 1990), p.3.

${ }^{13} J$ Jeanne Mccarten, Teaching Vocabulaty, Lesson From the Corpus, Lesson for theClassroom,(United State America, Cambridge university Press, 2007), p. 19

${ }^{14} \mathrm{H}$. DounglasBrown, Teaching By Principles An Interactive Approach to LanguagePedagogy, (United Stated Of America: Prentice Hall Regents, 1998), p. 365-366
} 
1. Allocate specific class time to vocabulary learning

2. Help students to learn vocabulary in context

3. Play down the roleof bilingual dictionaries

4. Encourage students to develop strategies for determining the meaning of words.

From four guidelines above it mean that when the teacher start to teach vocabulary, the teacher must attention all of the aspects that are related with teaching vocabulary.

When a teacher teaching material about vocabulary for students. The teacher must be attention principle to teaching vocabulary because teaching vocabulary is important to mastery in four skill. There are some principle to teaching vocabulary:

1. Focus on the most useful vocabulary firts

2. Focus on the vocabulary in the most appropriate way

3. Give attention the high frequency word across the four strands of a course.

4. Encourage learners to reflect on and take responsibility for learning. ${ }^{15}$

Moreover about principle to teaching vocabulary Tricia Hedge say some principle to teaching vocabulary, the teacher must be attent the principle there are:

1. Developing a variety of techniques for the teaching of meaning

2. Encouranging the development of effective strategies

3. Exposing learners to vocabulary through reading and training lexical inferencing

4. Teaching the effective use of dictionaries

5. Evaluating the vocabulary component of coursebooks

6. Teaching vocabulary explicitly through a range of activity types

7. Developing resources for vocabulary teaching. ${ }^{16}$

Based on the principles above, it show that principles is important in teaching especially principles to teaching vocabulary. So as a teacher must know and understand about principles of teaching vocabulary.

${ }^{15}$ David Nunan, Practical English Language Teaching, (New York: Mc Gran Hill, 2003), p. 135140.

${ }^{16}$ Tricia Hedge, Teaching and Learning in the Language Classroom, (United Kingdom: Oxford University Press, 2000), p. 125-135 
242 | TAZKIR: Jurnal Penelitian Ilmu-ilmu Sosial dan Keislaman

Vol. 03 No. 2 Desember 2017

\section{Word Square}

This research will use word square modeling to improve students' vocabulary mastery. Word square modeling is a learningmodeling that uses a box in the form of the puzzles. Crossword as a tool in delivering teaching material in the teaching and learning. Make the box is the main medium in transfer teaching material. ${ }^{17}$ Addition Word Square is the number of words that are arranges that the words can be read forward and backward". $1{ }^{2 \prime}$ Methods observations varied by Word Square means a way to teach the subject matter by getting students carefully observe an object that combine with Word Square". ${ }^{19}$

In learning Vocabulary word square just not one forms or Variation but so many types of word square, each types haves variation word such as horizontal and vertically, word random, diagonally, etc. So Word Square consists of five types as follow: ${ }^{20}$

1. Crosswords

2. Word Scramble

3. Word Search / Word Square

4. Cryptograms

5. Hangman

From explanation above,in this research researcher will be use types of number third that is word square because word square will help students to active their brain to searching vertical or horizontal answer in the box beside that words square like a games, it will be make students interesting, besides remembering words, it will be makestudents to think and find out where the correct words that is answer key to question.

This learning modeling is very good to use in process teaching and learning to improve student contemplative faculties randomly and make the students easy to understand the material. Student learning activities will improve by using this learning modeling because invite students to active to search a good

\footnotetext{
${ }^{17}$ Istarani, 58 Model Pembelajaraninovatif, (Medan: Media Persada, 2011), p. 181

${ }^{18}$ Robert Allen, Oxford pocket English dictionary (New York: Oxford University Press,1996), p.885

${ }^{19}$ Anonymous, "Model Pembelajaran Word

Square" (http://wyw1.wordpresscom/2009/11/14/model-pembelajaran-word-squareretrieved on Wednesday 06/may/2015 at 10.30 p. m)

${ }^{20}$ Mujiman, "Types Word Puzzle" (http://www.ehow.com/facts 5157113 typeswordpuzzles.html, Retrieved on sunday/26/April/2015 at 11.00 p. m)
} 
answer or line in the box that is considered correct with the question. So, the kindness of this learning modeling is as follows:

1. Words Square Modeling Can to facilitate students more easy to be mastering material because it has instructed to searching answer in the box.

2. Words Square Modeling Canto facilitate teacher is more easy to present material, because the teacher can instruct students to the box that has been prepared before.

3. Word Square Modeling Can to improvestudents' learning activities because it will be continue to hatch the letters in the box according to answer.

4. Words Square Modeling is Avoiding students not to bored because any activity doesn't makes students to be bored and tired follow the lesson.

Word Square have some disadvantages, there are some disadvantages of word square modeling:

1. Varies of box needs creativity of the teacher

2. We often found between box have been prepared, it doesn't matching with the question.

3. The question needs definitive answer needs high competence from a teacher.

\section{The Steps for Teaching Word Square}

Teacher must know many steps to use this learning modeling. There are steps to use it:

1. Teacher prepare worksheets thatwill be used in the teaching and learning

2. Students present the material according to the competency

3. Teacher divide a sheet activity according to the example

4. Students answer the question and hatching letter in the box according to the good answer.

5. Teacher gave answer for every answer in the box.

The words square modeling must have five minimum sentences. Make workgroup and they discusabout the sentences, if the result of group discussion haveclear or true, it is discusses again in the class.

\section{RESEARCH METHODOLOGY}

This research is designed by Classroom Action Research in which done to improve practice rather than to produce knowledge through diagnosis process, planning, action, observation, and reflection. The participants of this research is 
244 | TAZKIR: Jurnal Penelitian Ilmu-ilmu Sosial dan Keislaman

Vol. 03 No. 2 Desember 2017

grade VII SMP Negeri 5 Padangsidimpuan in academic 2014/2015. They are total 21 students and an english teacher of grade VII SMP Negeri 5 Padangsidimpuan. The researcher would observation activities in class when teacher conduct an action, and then the teacher would help the writer analyzes the data from the observation and make plane for each cycle. Technique of data analysis in this research is the reasearcher use quantitative and qualitative data. Qualitative is describe situation during the teaching process. Quantitative data was to collected and analyzed by computing the score of vocabulary test.

\section{FINDING AND DISCUSSION}

\section{General Findings}

Reseach result is the important things that present the quantitaive and qualitative data of Classroom Action research (CAR) in term of triangulation. In this chapter, the researcher would like to analyze each data that has been gotten from the teaching learning process. Finding based on the analysis of data collected from the implementation of word square modeling to improve students' vocabulary mastery in two cycles. Analysis also done with observation and interview.

Based on the result of action the first cycle and the second cycle, the researcher concludes that, students' vocabulary mastery could be improved through word square modeling. It can be seen from the result of test in the first cycle and test in the second cycle. This test showed that, there was improvement.

Based on the table above, the score means in cycle 1 was 73.1 but in the second cycle the score mean was 78.66, it means that there was improvement. Test was 25 items, so, the means score maximum 100. The means score increased 73.1 to become 78.66 . it was passed the minimum mastery criterion 75 , it is also could be seen from the percentage of students got score above 75 was $42.85 \%$ increased to become $76.19 \%$. To prove the significances, the researcher used $t$ test for samples less then 21 students,. The calculation result of $t_{0}=43.46, t_{\text {table }}$ with $\mathrm{df}=20$, level of significance in $\mathrm{t}$ table $5 \%$ is 2.086 it can be know that the result of $t_{0}$ is bigger than $t_{t}$, it is $43,46>2.08$. Based on the result, it means that there is a significant improvement between students' learning vocabulary process result in the first cycle and second cycle.

From analysis above the researcher concludes that the mean of first cycle and second cycle is a significantly difference, where mean of second cycle $(78,66 /$ 
$76,19 \%)$ is greater than first cycle $(73,1 / 42,85 \%)$. It shows that "Word Square Modeling improved students' vocabulary mastery at grade VII of SMP Negeri 5 Padangsidimpuan". With word square modeling in learning vocabulary, it made student more interactive.

\section{DISCUSSION}

Word square is concept that was given to students for making students could active to search good letter or word in the box. It also practice students to know good writing in every word because students more often false in manner writing a word. Learning with concept like this word square can make students imagination and activating brain. It also can to active students' speed to connection and search word in the box. Furthermore based on the related finding in this research, word square modeling is a new modeling in teaching vocabulary, like as in related finding; thesis of Parida Siregar ${ }^{21}$ which has done quantitative research collective data from grade $X$ at SMA Negeri 1 Barumun Tengah. This research conducted was two cycle. From the first and the second cycle, there were percentages in answering test. It is from $72 \%$ to become $96 \%$. The next is Wirda who found that the increasing scores of the students 48.21 to 56, and 8.29 to 50. There were was gotten 1876 word in first cycle and 2599 in second cycle. ${ }^{22}$ It is known that methods or techniques in teaching can help the students to learn vocabulary.

Finally, the research findings of this research was students' vocabulary mastery through word square modeling can improve. It means that, students' vocabulary mastery through word square at grade VII SMP Negeri 5 Padangsidimpuan is satisfactory. It can be seen from the result of data analyze increase of each cycle that has been gotten. In support to what has been done before that vocabulary can be taught by using mind mapping, it will be good for the students in order to help them in mastering vocabulary. ${ }^{23}$ It is also stated by Dini who found that Crossword Puzzle is good for vovabulary mastery ${ }^{24}$. Based

\footnotetext{
${ }^{21}$ Parida Siregar, Improving Students' Vocabulary Mastery Through Collaborative Learning Method. Unpublished Thesis,(Pdangsidimpuan : IAIN, 2013)

${ }^{22}$ WirdaHalawi, “Improving Grade V Vocabulary Mastery Using Antonym and Synonims at SD Negeri116254 RantoJior". Unpublished Thesis, (STAIN Padangsidimpuan, 2013)

${ }^{23}$ Eka Sustri Harida, “Using Mind Mapping Technique to Teach Vocabulary” 3, no. 1 (2015): 10, http://repo.iain-padangsidimpuan.ac.id/176/1/1. Eka -min.pdf.

${ }^{24}$ Dini Restu Profita, Gunarso Susilohadi, and Teguh Sarosa, “Improving English Vocabulary Mastery by Using Crossword Puzzle," English Education: Jurnal Pendidikan Bahasa Inggris Universitas Sebelas Maret 2, no. 2 (2014),
} 
246 | TAZKIR: Jurnal Penelitian Ilmu-ilmu Sosial dan Keislaman

Vol. 03 No. 2 Desember 2017

on the explanation above, it has been clear that using various kinds of methods in teaching will be more interesting for the students to learn. It can be concluded that the more interest students in learning, the more successful that the students will get.

When doing the research, the researcher found that some threat in this research. The first, based on the observation sheet, the researcher found that students still low motivation to study English. Because of most of the students in the first cycle didn't have full attention and looks confuse when the teaching learning process. So, the researcher tried to give them high motivation and made it in amusing case, the result, students more interest, felt happy, and also enjoy in teaching learning process.

When the action research was done, still there were some students become trouble makers. It made another students didn't concentration. The researcher felt difficult to handling the class, because they didn't hear the researcher as a teacher when explain the material, the result most of the students didn't understand or confused with material. Because of that, researcher makes one solution. The researcher gave more attention to them. They researcher asked them about where was the material didn't understand yet.

The researcher was as a teacher in this research. She was also as an observant, although English teacher was as a collaborator. The collaborator observed the researcher when the researcher doing action, when to observe the students the researcher was observant with collaborator teacher helped. The data was taken by test with any objective assessment. The action of the lesson plan also should be effective and efficient. So, the researcher concludes that the result of this research should be objective, and all the activities of this research should be presented in the real situation.

\section{CONCLUSION AND SUGGESTION}

\section{Conclusion}

As result of the research, researcher concludes that;

1. Based on this research, the hypothesis could be accepted. It could be seen by the calsulation result of $t_{o}=43.46$, table with $\mathrm{df}=20$, level of significance in $\mathrm{t}$ table $5 \%$ is 2.086 it can be know that the result of $t_{0}$ is bigger than $t_{t}$, it is

https://www.neliti.com/id/publications/60636/improving-english-vocabulary-mastery-by-usingcrossword-puzzle. 
$43,46>2.086$. It could be concluded that students' vocabulary mastery could improve through word square at grade VII SMP Negeri 5 Padangsidimpuan. By the mean score in the first cycle was 73.1 with the percentage $42.85 \%$, and the second cycle was 78.66 with percentage $76.19 \%$.

2. Some factors that influence students' vocabulary mastery through word square modeling are motivation, students who do disturbance.

\section{Suggestion}

As teachers of English, they must use various kinds of learning and teaching methods in order to make their students become more interested and motivated in learning. The teacher must be able to vary their materials and techniques. It is also suggested to the leader of the schools, they should make the facilities of learning complete to make the teachers have a creativity to use it. By many efforts of teaching and learning English, the teaching and learning process of English hopefully will be more increasingly. 
248 | TAZKIR: Jurnal Penelitian Ilmu-ilmu Sosial dan Keislaman

Vol. 03 No. 2 Desember 2017

\section{REFERENCES}

Arikunto, Suharsimi, Prosedur Penelitian Suatu Pendekatan Praktik. Jakarta:PT Rineka Cipta, 2006.

Allen, Robert, Oxford pocket English dictionary, New York: Oxford University Press,1996.

Brown,Dounglas, Teaching By Principles An Interactive Approach to Language Pedagogy. United Stated Of America: Prentice Hall Regents, 1998.

Brno, “TestngVocabulary"(is.muni.cz/th/152699/pedf_m/Testing_Vocabulary.pdf.

Burridge, Shirley, Oxford Basic English Dictionary. New York: Oxford University Press, 1981.

Dakshina, Jayanti, Contemporary English Grammar, (New Delhi: Book Place, 2003.

Evely, Marcusen, Vocabulary Semantic and Language Education. Cambridge: University Press, 1997.

Frank,Marcella,Modern English A Practical Reference Guide. Ney York: Prentice Hall, 1972.

Harida, Eka Sustri. "Using Mind Mapping Technique to Teach Vocabulary" 3, no. 1 (2015): 10. http://repo.iain-padangsidimpuan.ac.id/176/1/1. Eka min.pdf.

Harmer, Jeremy, the Practical of English Language Teaching. New York: Longman, 2000.

Hartono, John, Accurate, Brief and Clear English Grammar. Surabaya:Indah, 2009.

Hedge, Tricia, Teaching and Learning in the Language Classroom. United Kingdom: Oxford University Press, 2000.

Hornby, A S,Oxford Advanced Learner's Dictionary of Current English. Oxford University Press, 1995.

Istarani, 58 inovatif Learning modeling. Medan: Media Persada, 2011.

Jackson, Howard, Word, Meaning and Vocabulary. London: Creswell, 2000.

Kunandar, Langkah Mudah Penelitian Tindakan Kelas Sebagai Pengembang Profesi Guru. Jakarta: PT. Raja Grafindo Persada, 2012. 
Mallery, Richard, How to Enlarge and Improve your Vocabulary. United state, America: The Blakiston Company, 1947.

Martin, and Wren, High School English Grammar and Composition, ( Jakarta: Persada Rao, 1990.

Martinet, and Thomson, A Practical English Grammar. Hong Kong: Oxford University Press, 1985.

Maya Sari, Nia, The Effect of Using Card Media on Students' Vocabulary Achievement. University: Medan, 2011.

Mccarten, Jeanne, Teaching Vocabulaty, Lesson From the Corpus, Lesson for the Classroom. United State America: Cambridge university Press, 2007.

Mujiman,“TypesWordPuzzle"(http://www.ehow.com/facts_5157113_types wordpuzzles.html.

Nugroho, Satrio, Complete English Grammar, Tata Bahasa Inggris Lengkap. Surabaya:Kartika, 2008.

Nunan, David, Practical English Language Teaching. New York: Mc Gran Hill, 2003.

Profita, Dini Restu, Gunarso Susilohadi, and Teguh Sarosa. "Improving English Vocabulary Mastery by Using Crossword Puzzle." English Education: Jurnal Pendidikan Bahasa Inggris Universitas Sebelas Maret 2, no. 2 (2014). https://www.neliti.com/id/publications/60636/improving-englishvocabulary-mastery-by-using-crossword-puzzle.

Renandya, and Richard, Methodology in Language Teaching and Anthology of Current Practice. USA:Cambridge University Press, 2000.

Retor airasion, and L.R. Gay, Educational Research. New Jersey:Prentice Hall, 2000.

SMP Negeri 5 Padangsidimpuan, Perangkat Pembelajaran Panduan Pengembangan Silabus Pembelajaran. Padangsidimpuan: 2014.

Zuber Skerrit, Ortrun, New Direction in Action Research. London: The Falmer Press, 1996. 
250 | TAZKIR: Jurnal Penelitian Ilmu-ilmu Sosial dan Keislaman Vol. 03 No. 2 Desember 2017

The Effect of Reciprocal Teaching Strategy

on Students' Reading Comprehension in Narrative Text at Grade IX of SMP $n 5$ Panyabungan

NUR INAYAH HASIBUAN

IAIN Padangsidimpuan 